\title{
Persepsi Peserta Didik terhadap Pelaksanaan Bimbingan dan Konseling di Sekolah Menengah Atas Negeri 1 Karya Penggawa Kabupaten Pesisir Barat
}

\author{
Busmayaril, Heldayani \\ Dosen dan Mahasiswa Fakultas Tarbiyah dan Keguruan, IAIN Raden Intan Lampung
}

Diterima: April 2016. Disetujui: Mei 2016. Dipublikasikan: Juni 2016

\begin{abstract}
Abstrak: Penelitian ini bertujuan untuk mengetahui persepsi peserta didik terhadap pelaksanaan bimbingan konseling di SMA Negeri I Karya Penggawa Kabupaten Pesisir Barat. Penelitian ini menggunakan metode penelitian kualitatif dengan subyek penelitian sebanyak 8 orang, 6 peserta didik, 1 kepala sekolah,1 guru BK SMA Negeri I Karya Penggawa Kabupaten Pesisir Barat dari kelas (kelas X, XI dan XII) dengan teknik snowball sampling. Pengumpulan data menggunakan pedoman wawancara yang telah disusun oleh peneliti dan dokumen analisis. Data yang terkumpul ditranskipkan satu persatu, kemudian dianalisissecara tematik berdasarkan teori yang dijadikan landasan dalam penelitian.Hasil penelitian menunjukkan bahwa, persepsi peserta didik terhadap pelaksanaan bimbingan konseling di SMA N I Karya Penggawa Kabupaten Pesisir Barat tahun Pelajaran 2015/2016 antara lain: (a) bahwa bimbingan dan konseling untuk membantu dalam mengatasi masalah-masalah yang diatasi oleh peserta didik dalam konotasi negative (nakal, suka membolos, tidak disipilin dll); (b) bimbingan dan konseling ini kurang berfungsi memberikan layanan peserta didik secara maksimal. Fungsi bimbingan dan konseling yang dilaksanakan lebih dominan pada fungsi pengentasan yaitu ketika peserta didik melakukan tindakan-tindakan yang melanggar aturan sekolah; (c) kurangnya fasilitas sarana dan prasarana bimbingan dan konseling yang disediakan oleh sekolah (tidak ada ruang khusus untuk konseling); (d) minimnya pengetahuan peserta didik tentang pelaksanaan bimbingan dan konseling (tujuan, metode, fungsi, prinsip) sehingga tidak banyak peserta didik yang mengakses layanan bimbingan dan konseling; (e) minimnya keterampilan guru bk dalam pelaksanaan bimbingan dan konseling, sehingga layanan BK kurang memberikan pelayanan yang bersifat preventif dan pengembangan dan cenderung menyalahkan peserta didik. Berdasarkan hasil dari penelitian secara keseluruhan dapat disimpulkan bahwa persepsi peserta didik terhadappelaksanaan bimbingan dan konseling di SMA N I Karya Penggawa Kabupaten Pesisir Barat tahun Pelajaran 2015/2016 ini kurang maksimal.
\end{abstract}

Kata Kunci: Persepsi, Bimbingan Konseling

\section{Pendahuluan}

Sejarah perkembangan bimbingan dan konseling Indonesia khususnya di sekolah secara resminya bermula dengan program bimbingan karir yang diperkenalkan dalam tahun-tahun enam puluhan apabila konsep guru panduan karir mulai diperkenalkan dalam sistem persekolahan di Malaysia (Amla, Zuria dan Salleh, 2001). Kini layanan konseling telah mendapat tempat yang sewajarnya di Indonesia dan Malaysia. Pada masa ini bisalah dianggap konseling sebagai satu profesi yang menantang di Negara kita.

Kesungguhan kerajaan untuk menjadikan konseling sebagai satu profesi di Malaysia tercapai apabila kerajaan meluluskan undang-undang berkaitan dengan Akta Kaunselor 1998 (Undang- Undang Malaysia, 1998). Hasilnya hanya kaunselor-kaunselor yang terdaftar saja yang dibenarkan untuk menjalankan layanan kaunseling secara professional dan menggunakan nama jabatan sebagai kaunselor.

Namun demikian kemahiran- kemahiran asas kaunseling boleh diaplikasikan dalam sistem pendidikan dan digunakan oleh guru-guru biasa dalam membantu para peserta didik serta digunakan diwaktu proses belajar mengajar dalam kelas. Berhubungan dengan itu, penulisan ini mencoba untuk menerapkan aspek-aspek kaunseling dalam pembinaan kurikulum Islam dengan memberi fokus kepada aspek guru yang bertanggung jawab melaksanakan kurikulum dan juga aspek peserta didik yang menerima pendidikan yang di berikan oleh guru. 
Secara umumnya, tujuan utama pendekatan counseling diperkenalkan adalah untuk membantu peserta didik. Islam membuat tindakan yang seksama dalam mengahadapi perubahan, tantangan atau masalah. Ia juga boleh memberikan nasehat yang terus menerus kepada pelajaran- pelajaran dan pembentuk psikologi, mental, emosi dari dalam diri mereka.

Diera globalisasi ini, manusia semakin menghadapi berbagai bentuk tantangan yang bisa membawa kepada permasalahan didalam ummat Islam, khususnya dan generasi muda pada umumnya. kelahiran biadang kaunseling serta kaunselor diharapkan dapat membantu para pendidik menangani masalah remaja yang semakin menantang. Islam pada prinsipnya meminta setiap umat islam menjadi kaunselor dan para rasul dan utusan Allah adalah contoh teladan yang terbaik dan gigih memainkan peranan dalam bidang kaunseling. Dengan kata lain, konseling sebenarnya telah lama wujud didalam islam. Semuanya para rasul adalah bertujuan memberikan nasehat dan membawa kebenaran yang hakiki disisi Allah swt (Al- Quran: 2:143,5:87-88,16:8). Dari perspektif islam, konseling adalah untuk ummat digalakkan dan kaedah umum konseling berasaskan kepada firman Allah SWT: "serulah kejalan tuhanmu (wahai Muhammad) dengan hikmah kebijaksanaan dan nasehat pengajaran yang baik" (AlQuran 16:125)

\section{Metode Penelitian}

Dalam penelitian ini menggunakan pendekatan kualitatif. Menurut Sugiyono penelitian kualitatif adalah suatu metode penelitian yang berlandaskan pada filsafat postpositivisme, digunakan untuk meneliti pada kondisi objek yang alamiah dimana peneliti adalah sebagai instrumen kunci, pengambilan sampel sumber data dilakukan secara purposive, teknik pengumpulan dengan analisis data bersifat induktif/kualitatif, dan hasil penelitian kualitatif lebih menekankan makna daripada generalisasi. Penelitian kualitatif bertumpu pada latar belakang alamiah secara holistik, memposisikan manusia sebagai alat penelitian, melakukan analisis data secara induktif, lebih mementingkan proses daripada hasil serta hasil penelitian yang dilakukan disepakati oleh peneliti dan subjek penelitian. Metode penelitian kualitatif sering disebut metode penelitian naturalistik karena penelitiannya dilakukan pada kondisi yang alamiah (natural settting). Dalam pandangan penelitian kualitatif, gejala itu bersifat holistik (menyeluruh, tidak dapat dipisah-pisahkan), sehingga peneliti kualitatif tidak akan menetapkan penelitiannya hanya berdasarkan variabel penelitian, tetapi keseluruhan situasi sosial yang diteliti.

\section{Hasil dan Pembahasan}

Menurut kepala sekolah, "guru BK di SMA N I Penggawa Kabupaten Pesisir Barat memiliki kemampuan dalam pelaksanaan bimbingan dan konseling dengan baik untuk peserta didik. Indikatornya dilihat dari keseharian perilaku guru BK dalam pelaksanaan menunjukkan sikap yang baik, memiliki kesabaran dalam menghadapi peserta didiknya, memberikan arahan dan membimbing dalam layanan bimbingan dan konseling untuk mengatasi masalah- masalah peserta didik".

Adapun sikap yang ditujukan guru BK dalam proses pelaksanaan bimbingan dan konseling yaitu guru BK berusaha memberikan yang terbaik bagi peserta didik terhadap berbagai masalah yang dihadapi peserta didik dan berusaha selalu memberikan bimbingan dan bantuan untuk mengatasi masalah-masalah yang dihadapi. Dengan demikian guru BK mengungkapkan bahwa, persepsi peserta didik terhadap pelaksanaan bimbingan dan konseling di SMA Negeri I Penggawa Kabupaten Pesisir Barat:

1. Peserta didik selalu takut dan mengira akan dimarahi ketika menghadapi konselor (guru $\mathrm{BK})$ 
2. Peserta didik tidak mau membicarakan persoalannya secara terbuka kepada guru BK karena merasa malu jika persoalannya diketahui.

Sementara persepsi yang diberikan peserta didik terhadap guru BK di SMAN I Penggawa Kabupaten Pesisir Barat, dipahami sebagai pembimbing, pemberi nasehat dan yang mengarahkan peserta didik mengentaskan permasalahannya. Menurut Indah, guru BK selalu mengawasi dalam kedisiplinan tata tertib sekolah.

Hasil wawancara dengan peserta didik SMAN I Penggawa Kabupaten Pesisir Barat diperoleh informasi pengetahuan peserta didik tentang bimbingan dan konseling disekolah. Seluruh subyek penelitian mengatakan bimbingan dan konseling dipahami sebagai tempat menangani peserta didik yang nakal, bermasalah, tempat guru menasehati peserta didik yang bandel dan identik dengan image guru BK yang galak, garang, ditakuti peserta didik. Tidak semua peserta didik memiliki pemahaman mengenai metode/cara-cara yang dilakukan guru BK dalam pelaksanaan bimbingan konseling. Pendekatan - pendekatan personal kepada peserta didik yang selama ini dilakukan agar peserta didik lebih terbuka.

Pemahaman peserta didik mengenai tujuan bimbingan konseling masih sangat kasuistik belum menyeluruh, untuk mendisiplinkan peserta didik yang mengalami masalah "nakal" dengan mengintrogasi peserta didik. Jika di sekolah tidak terdapat guru BK maka tidak ada yang mendisiplinkan peserta didik. Sehingga fungsi bimbingan dan konseling masih dipahami untuk pengentasan masalah saja seperti untuk membimbing (dalam konteks permasalahan), melakukan pendekatan kepada peserta didik dan mengintrogasi peserta didik yang nakal.

Secara umum, subyek dalam penelitian tidak mengatahui konsep pelaksanaan bimbingan dan konseling di sekolah yang notabanenya untuk membantu peserta didik mencapai perkembangan potensi secara optimal sehingga mampu mencapai tugas- tugas perkembangannya baik aspek pribadi sosial, belajar dan karir mencapai peserta didik yang mandiri. Selama ini subyek penelitian tidak pernah mendapat informasi secara detail tentang apa itu bimbingan dan konseling, apa azas- azas, bidang-bidang, prinsip dan layanan yang harus ada dalam setiap pelaksanaan bimbingan dan konseling. Peserta didik hanya mengenal bimbingan dan konseling untuk memanggil peserta didik yang nakal tanpa mencari tahu penyebabnya, langsung memvonis peserta didik nakal. Selain itu, kerahasiaan peserta didik tidak terjamin. Peserta didik merasakan selama ini jarang melakukan konsultasi dengan guru BK. Tidak ada ruang khusus untuk bimbingan konseling sehingga peserta didik merasa malu jika harus menceritakan permasalahannya karena akan diketahui pihak lain. selama ini layanan bimbingan dan konseling yang diperoleh untuk pemilihan jurusan dan mengatasi anak-anak yang suka membolos, terlambat itu pasti dipanggil guru BK. Namun pada dasarnya mereka memahami bahwa pelaksanaan Bimbingan dan Konseling memiliki peranan penting untuk menertibkan dan mendisiplinkan peserta didik agar sesuai dengan aturan yang ada di sekolah. Harapan peserta didik yang diwawancara agar pelayanan bimbingan dan konseling dapat menjadi tempat yang nyaman dan asyik untuk menyelesaikan masalah

Persepsi yang terjadi pada peserta didik di atas dapat dijadikan indikator bahwa pemahaman peserta didik terhadap pelaksanaan bimbingan dan konseling masih kurang. Konselor dan guru berkewajiban membantu peserta didik untuk meningkatkan pemahaman persepsi peserta didik terhadap pelaksanaan bimbingan dan konseling sehingga peserta didik dapat benar-benar memanfaatkan layanan bimbingan dan konseling yang ada secara maksimal.

Keberadaan bimbingan dan konseling di sekolah sangat penting sekali, karena bimbingan dan konseling berfungsi membantu dalam usaha mencapai tujuan pendidikan. Bimbingan dan konseling merupakan proses pemberian bantuan kepada individu untuk dapat mengatasi hambatan perkembangan yang dialamai oleh peserta didik. Bimbingan tidak dapat dipisahkan dengan konseling karena bimbingan merupakan bagian integral dari konseling. Bimbingan dan konseling merupakan bagian integral dan tidak terpisahkan dari proses pendidikan dan memiliki kontribusi terhadap keberhasilan proses pendidikan di sekolah. 
Artinya proses pendidikan dan pembelajaran di sekolah tidak akan memperoleh hasil yang optimal tanpa didukung oleh penyelenggaraan layanan bimbingan dan konseling yang baik.

Menurut prayitno, bimbingan adalah proses pemberian bantuan yang dilakukan oleh orang yang ahli kepada seseorang atau beberapa orang individu, baik anak-anak, remaja maupun dewasa agar orang yang dibimbing dapat mengembangkan kemampuan dirinya sendiri dan mandiri dengan memanfaatkan kekuatan individu dan sarana yang ada dan dapat dikembangkan berdasarkan norma-norma yang berlaku". Adapun pengertian konseling adalah proses pemberianbantuan yang dilakukan melalui wawancara konseling oleh seseorang ahli (konselor) kepada individu yang sedang mengalami suatu masalah (konseli) yang bermuara pada teratasinya masalah yang dihadapi oleh konseli.

Pada pelaksaaan bimbingan dan konseling akan banyak penafsiran yang berbeda-beda dari setiap individu di sekolah. Hal ini terjadi manakala masing-masing individu di sekolah menafsirkan pelaksanaan bimbingan dan konseling dari sudut pandang mereka sendiri sesuai dengan pemahaman yang mereka punyai bukan berdasarkan pada prinsip-prinsip pelaksanaan bimbingan dan konseling. Terjadinya perbedaan bagi tiap individu dengan persepsi suatu Objek tergantung pada pengalaman dan pengamatan individu itu sendiri terhadap Objek yang sama apabila antara mereka ada yang sebelumnya telah memiliki pengalaman tentang Objek tersebut dan yang lainnya belum/tidak memiliki pengalaman Objek itu.

Bimbingan dan konseling sangat penting dan dibutuhkan oleh setiap individu atau kelompok untuk menanggulangi atau mengatasi problem-problem yang timbul baik dalam keluarga, sekolah maupun masyarakat. Terutama di sekolah, bimbingan dan konseling sangat dibutuhkan untuk menanggulangi problem yang terjadi pada peserta didik dan mampu mengatasi hambatan-hambatan dalam proses perkembangannya sehingga dapat menjalani proses perkembangan dengan optimal dan mandiri.

Dalam implementasi pelaksanaan program dan layanan bimbingan dan konseling masih banyak yang belum dilaksanakan secara maksimal. Masih tingginya kesalahpahaman dalam pelaksanaan dan layanan bimbingan dan konseling memunculkan persepsi yang berbeda-beda terhadap pelaksanaan bimbingan dan konseling. Menurut prayitno,

ada beberapa kesalahpahaman dalam pelaksanaan bimbingan dan konseling diantaranya:

1. Bimbingan dan Konseling disamakan atau dipisahkan sama sekali dari pendidikan

2. Menyamakan pekerjaan Bimbingan dan Konseling dengan pekerjaan dokter dan psikiater

3. Bimbingan dan Konseling dibatasi pada hanya menangani masalah- masalah yang bersifat insidental.

4. Bimbingan dan Konseling dibatasi hanya untuk peserta didik tertentu saja.

5. Bimbingan dan Konseling melayani "orang sakit" dan/atau "kurang/tidak normal"

6. Bimbingan dan Konseling menangani masalah yang ringan

7. Petugas Bimbingan dan Konseling di sekolah diperankan sebagai "polisi sekolah".

8. Bimbingan dan Konseling dianggap semata-mata sebagai proses pemberian

1. nasihat.

9. Menganggap pekerjaan bimbingan dan konseling dapat dilakukan oleh siapa saja dll.

Hal tersebut diperkuat dengan hasil penelitian yang dilakukan peneliti tentang persepsi peserta didik terhadap pelaksanaan bimbingan dan konseling di SMA N I Karya Penggawa Kabupaten Pesisir Barat, baik positif maupun negative:

1. Bahwa bimbingan dan konseling untuk membantu dalam mengatasi masalah- masalah yang diatasi oleh peserta didik. Masalah-masalah tersebut lebih dominan pada pelanggaranpelanggaran aturan sekolah (membolos, terlambat, tidak memakai atribut sekolah, dll) dengan demikian bahwa guru BK di SMA N I Karya Penggawa Kabupaten Pesisir Barat kurang membantu peserta didik dalam mengatasi masalah- masalah yang dihadapinya, oleh 
karena itu sebagian peserta didik masih ada yang belum tahu tentang pelaksanaan bimbingan dan konseling disekolah.

2. Fungsi BK, Dengan keberadaan bimbingan dan konseling di SMA N I Karya Penggawa Kabupaten Pesisir Barat bahwa guru BK berfungsi untuk membantu kepala sekolah, guru dan pihak-pihak lainya untuk memahami dan mengetahui tentang identitas pribadi dan latar belakang keluarga peserta didik dan guru BK juga dapat membantu peserta didik untuk memahami kegiatan ektrakulikuler di sekolah. Namun dengan demikian bahwa guru BK di SMA N I Karya Penggawa Kabupaten Pesisir Barat kurang memberikan bantuan bimbingan dan konseling terhadap peserta didik dalam mengatasi masalah-masalah yang sedang dihadapi oleh peserta didik dan guru BK tersebut tidak memberikan jalan keluarnya dalam mengatasi masalah-masalah yang dihadapinya, serta guru BK juga tidak memberikan bimbingan kepada peserta didik dalam mentaati tata tertib disiplinnya di sekolah maka dengan demikian peserta didik di SMA N I Karya Penggawa Kabupaten Pesisir Barat masih banyak yang melanggar peraturan di sekolah. Fungsi bimbingan dan konseling masih diimplentasikan fungsi kuratifnya saja, fungsi lainnya belum dijalankan maksimal.

3. Manfaat BK, Jadi guru BK di SMA N I Karya Penggawa Kabupaten Pesisir Barat ini sangat bermanfaat untuk semua pihak-pihak yang ada disekolah karena dengan adanya guru BK ini untuk dapat membantu dalam mengatasi masalah- masalah dan dapat mengembangkan potensi, bakat, dan minat peserta didik. Namun dalam pelaksanaan pelayanan belum dilakukan secara maksimal sehingga belum memberikan manfaat yang signifikan bagi perkembangan peserta didik

4. Sarana dan prasarana BK, Sarana dan prasarana bimbingan dan konseling di SMA N I Karya Penggawa Kabupaten Pesisir Barat belum disediakan secara khusus untuk ruangan bimbingan dan konseling maka pelaksanaan bimbingan dan konseling belum dapat terlaksana dengan baik. Sarana dan prasarana bimibingan dan konseling di SMA N I Karya Penggawa Kabupaten Pesisir Barat ini masih kurang memadai, tempat yang disediakan belum memiliki ruangan konseling secara pribadi dan masih digabungkan dengan ruangan bimbingan dan konselig atau rungan lain. sehingga peserta didik tidak merasa nyaman berbicara secara terbuka dan merasa takut jika permasalahannya diketahui guruguru lain

5. Tekhnik BK, Dengan cara tekhnik bimbingan dan konseling ini antara guru BK dengan peserta didik sudah sangat akrab dalam pelaksanaan bimbingan dan koseling dan guru BK hanya menggunakan tekhnik cara klasikal dan tekhnik cara alih tangan. Namun guru BK kurang menggunakan tekhnik cara kelompok dan individual dalam pelaksaan bimbingan dan konseling dan menggunakan punishman untuk memberikan efek jera serta panggilan orang tua kepada peserta didik yang bermasalah.

6. Layanan BK, Dalam layanan bimbingan dan konseling ini guru BK di SMA N I Karya Penggawa Kabupaten Pesisir Barat ini kurang membantu peserta didik dalam menempatkan pada bakat dan minatnya peserta didik tentang kegiatan ektrakulikuler yang ada di sekolah, namun masih banyak juga peserta didik yang tidak pernah berkonsultasi terhadap guru BK secara pribadi dan guru BK juga tidak pernah menggunakan layanan kunjungan ke rumah peserta didik. Artinya proses layanan bimbingan dan konseling belum dilaksanakan secara menyeluruh dan komprehensif oleh guru bimbingan dan konseling dan belum diakses oleh seluruh peserta didik

7. Kemampuan guru BK, Guru BK kurang kemampuan dalam mengatasi masalah- masalah yang dihadapi oleh peserta didik, maka dengan demikian peserta didik bertanggapan (persepsi) terhadap guru BK tidak menanggapi dan tidak membantu memecahkan masalah peserta didik disaat peserta didik berkonsultasi kepada guru BK. 
Maka analisis diatas dapat disimpulkan bahwa persepsi peserta didik terhadap pelaksanaan bimbingan dan konseling di SMA N I Karya Penggawa Kabupaten Pesisir Barat masih mempunyai tanggapan yang negatif terhadap pelaksanaan bimbingan dan konseling di sekolah, maka dengan demikian pelaksanaan bimbingan dan konseling kurang berjalan maksimal dan memberikan manfaat bagi peserta didik.

\section{Simpulan dan Saran}

Berdasarkan hasil penelitian, penulis menarik kesimpulan bahwa hasil penelitian dan data sosiometri diperoleh data 3 peserta didik yang mengalami masalah kurang minat belajar pada mata pelajaran Bahasa Inggris, kemudian peneliti melakukan konseling pada ketiga peserta didik tersebut dengan menggunakan pendekatan client centered dalam meningkatkan minat belajar peserta didik pada Mata Pelajaran Bahasa Inggris sebanyak 3 kali sesi konseling. Pada sesi pertama klien bersama- sama dengan peneliti (selaku guru BK) mengenali masalah yang sedang dihadapi klien dan menginisiasi alternative pemecahan masalah, selanjutnya pada sesi ketiga klien bersama-sama peneliti melakukan pendalaman permasalah dan evaluasi alternative solusi pada sesi pertama, sesi terakhir klien melakukan pemantapan solusi berdasarkan pengalaman alternative solusi pada sesi sebelumnya. Setelah pelaksanaan sesi konseling, peneliti melakukan penilaian hasil layanan konseling tersebut dan observasi hasil pemberian layanan. Berdasarkan hasil sesi konseling, dapat disimpulkan bahwa terdapat perubahan minat belajar dalam mata pelajaran bahasa inggris peserta didik MTs Mathla'ul Anwar Cintamulya dengan pendekatan Client Centered dengan cara dan teknik belajar sesuai dengan minat masing- masing.

\section{Daftar Pustaka}

Al-Qur'an dan terjemah. Departemen Agama RI

Bimo Walgito. 2004. Pengantar Psikologi Umum. Yogyakarta: Andi

Boeree C. George. 2008. General Psichology. Jakarta: Primasophie

Chaplin James P. 2011. Kamus Lengkap Psikologi. Jakarta: Rajawali Pers

Deddy Mulyana. 2005. Ilmu Komunikasi: suatu pengantar. Bandung: Remaja Rosda Karya

Desmita. Wawancara Guru Bimbingan dan Konseling. 5 Oktober 2014

Dewa Ketut Sukardi. 2008. Bimbingan dan Konseling di Sekolah. Jakarta: Rineka Cipta

Guidanceforal, pada 9 Desember 2012 in Seminar BK (Online)

http://guidanceforal.wordpress.com/2012/12/09/persepsi-siswa-terhadapkeberadaan konselor

Hellen. 2005. Bimbingan dan Konseling. Jakarta: Ciputat pers

Iqbal. M. Hasan. 2002. Metodologi penelitian dan aplikasinya. Jakarta : Ghalia Indonesia

Jalaluddin Rakhmat. 2001. Psikologi Komunikasi. Bandung: Remaja Rosdakarya

Koentjarangingrat. 1993. Metode Penelitian Masyarakat. Jakarta : PT Gramedia

Moleong Lexy J. 2002. Metodologi Penelitian Kualitatif. Bandung : Remaja Rosdakarya

Prayitno. 2009. Dasar-dasar Bimbingan dan Konseling. Rineka Cipta : Jakarta

Pujaatmaka Hadyana \& Molan Benyamin. 2006. Terjemah Organization Theory : Structure, Design andApplications

Rizka Annisa Mardiana. Jurnal BK UNESA. Volume 3 Nomer 1. $72-8072$ 
Singarimbun Masri \& Efendi Sofian. 1989. Metode Penelitian Survei Jakarta : LP3ES

Slamoto. 2003. Bimbingan diSekolah,. Jakarta: Bina Aksara

Sugiyono. 2009. Metode Penelitian Kuantitatif Kualitatif dan R\&D. Bandung : Alfabeta 2011. Metode Penelitian Kuantitatif Kualitatif dan R\&D. Bandung : Alfabeta

Suharsimi. Arikunto 2000. Prosedur Penelitian Suatu Pendekatan Praktek. Jakarta : Rineka Cipta

Sutrisno Hadi. 1999. Metodologi Research Jilid 2. Yogyakarta : Andi Offset

Tohirin. 2007. Bimbingan Dan Konseling Di Sekolah Dan Madrasah (Berbasis Integrasi). PT Raja Grafindo Persada: Jakarta

Umar M. \& Sartono. 1998. Bimbingan Dan Penyuluhan. Pustaka Setia: Bandung 
